\title{
Influence of Social Capital on Consumption Per Capita Income and Poverty Alleviation in Tertiary Institution Cooperative Thrift and Credit Society
}

\author{
Kabiru Jinjiri Ringim \\ School of Business, Universiti Teknologi Brunei, Brunei Darussalam \\ Sayedi Ndagi Shuaib \\ Department of Business Administration, Faculty of Management and Social Sciences, \\ Ibrahim Badamasi Babangida University, Lapai, Niger State
}

\section{Doi:10.5901/mjss.2017.v8n3p35}

\section{Abstract}

This study investigated the influence of social capital on members' consumption per capita income and poverty alleviation in Cooperative Thrift and Credit Society of Federal Polytechnic Bida, Niger state- Nigeria. Low income level and poverty influence the employees of the polytechnic to partake in cooperative society through the contribution of money/credit referred to as social capital. Data were collected using field research survey approach involving hand delivery of questionnaire. Simple random technique of probability sampling method was used to draw a sample size of 255 members from the population of 702 academic and non- academic members of the cooperative society. The regression results indicated that social capital dimension such as educational qualification and membership duration has significant influence on consumption while social capital indicator such as income and educational qualification has significant influence on poverty alleviation. Other variables such as gender, marital status, work status and savings were insignificant. The study therefore recommends that regulators and policy makers should encourage savings mobilization from members' income or salary in order to boost consumption and alleviate poverty. This is because income has insignificant influence on consumption and significant influence on poverty alleviation in Cooperative Thrift and Credit Society of Federal Polytechnic Bida, Niger state. The results of this study are unique and worth in solving problems that are facing cooperative associations in Nigeria.

Keywords: Social capital, Per-capita income, Poverty Alleviation, Cooperative Thrift and Credit Society

\section{Introduction}

There is a growing detection that differences in economic outcomes, whether at the individual, household or at the level of the state, cannot be explained fully by differences in the traditional inputs such as labour, land, and physical capital. Growing attention is now given to the role of social capital and its influence on the poverty reduction and well-being of members/households as well as level of development of cooperative unions, communities and nations. The influence of cooperative society or union can never be overemphasized. This is because cooperative society's social capital contributes greatly to poverty reduction and expenditure per capita income of members as well as economic development of the nations. In most developing countries like Nigeria, no record showing the contribution of cooperatives association to economic growth due to negligence in data keeping. Hence, the importance of cooperative unions are beginning to be felt because of the persist poverty among people of low income group. In the past, the strategy to reduce poverty in Nigeria consists of two main elements. The first element is to increase the income and productivity of the poor. This was to be achieved by expanding their productive capital as well as increasing their efficiency and productivity such as by adopting modern techniques, replanting and redevelopment of crops, irrigation, introduction of new crops, and improved marketing, credit, financial and technical assistance. The second is to improve the quality of life of the poor by provision of social services such as housing, health, education and public utilities (Yusuf, 2008).

Poverty reduction has been receiving increasing global attention more importantly in the developing countries where majority of the people are considered poor. The need to reduce poverty to the barest minimum has been the major 
concern of the Millennium Development Goals (MDG) (Adepoju and Oni, 2012). Thus, social capital which may be a product of cooperative societies might influence members' consumption per capita income and poverty alleviation. This is because the money gathered through the members' effort are used to settle households' problems, establishment of selfemployed businesses, payment of school fees, purchase of automobiles, building of houses, etc. ljaiya, Sakariyau, Dauda, Paiko and Zubairu, (2012) showed social capital indicators having significant relationship with poverty reduction. Also, Baiyegunhi (2013) identified economic status has significant effect on welfare of members. However, previous studies conducted on occupational cooperative society by authors such as Adepoju and Oni, (2012); ljaiya, Sakariyau, Dauda, Paiko and Zubairu, (2012); Baiyegunhi (2013) argued on some setbacks regarding poverty alleviation that were associated with farmers' or traders' cooperative societies and few studies were conducted on institutional cooperative societies. This study replicate the previous studies of Oseni, Ogunniyi, and Sanni (2012) conducted in Nigerian Higher institution with slight modifications on its weakness in social capital index which are lacuna in the field of academic discussions. The core research question of this study is therefore to examine to what extent social capital influences consumption per capita income and poverty alleviation in Tertiary institution cooperative society? Hence, the specific objectives of this study are: 1) To determine the influence of social capital on consumption per capita income of registered members of Tertiary Institution Cooperative Thrift and Credit Society (CT\&CS); 2) To examine the influence of social capital on poverty alleviation of registered members in Tertiary Institution CT\&CS.

\section{Review of Related Literature}

\subsection{Poverty and Poverty Alleviation}

There are different definitions of poverty. The definitions of poverty can be statistical or expert/people derived ones. Statistical definitions refer to definitions of poverty that tend to use figures, numbers and percentages to define poverty. For instance, World Bank defines poverty as any income below US $\$ 1.25$ a day for the poorest countries and US $\$ 2$ a day for poor developing countries. Expert-derived definitions of poverty are those definitions coined by development experts. These experts could be development researchers and practitioners, economists, social scientists etc (Nyasulu, 2010). In our opinion, poverty may be define as condition where people's basic needs for food, clothing, shelter and money for emergency purposes is not being met. Aluko (1975) in lbrahim and Mohammed (2009) refer to poverty as a lack of command over basic needs. The basic needs include food, shelter and money such as money needed for emergency purposes and money needed for the payment of rented apartments, school fees, utility bills, hospital bills etc. Aku, et. al (1997) in ljaiya et al. (2012) sees poverty from five dimensions of deprivation: (i) personal and physical deprivation experienced from health, nutritional, literacy, educational disability and lack of self-confidence; (ii) economic deprivation drawn from lack of access to property, income, assets, factors of production and finance; (iii) social deprivation as a result of denial from full participation in social, political and economic activities; (iv) cultural deprivation in terms of lack of access to values, beliefs, knowledge, information and attitudes which deprives the people the control of their own destinies; and (v) political deprivation in term of lack of political voice to partake in decision making that affects their lives. The operational definition of poverty in this study is the concept of poverty based on standard of living of people in an area or country. In Nigeria, poverty alleviation measures focus on improved standard of living, per capital income of citizens or real GDP per capital among others. Poverty can be measured via objective and subjective measurements. The objective measurement is by macro-economic stability and basic needs (Yusuf at al., 2009). But subjective measurement is by improving standard of living of people in a particular area. According to United Nations Development Programme- UNDP (2009) in ljaiya et al. (2012), Human Development Index-HDI combines three components in the measurement of poverty: (i) life expectancy at birth (longevity); (ii) education attainment and; (iii) improved standard of living determined by per capita income.

\subsection{Social Capital}

The concept of social capital is a multidimensional one and there is no unique definition commonly accepted within the social sciences research scholars. Social capital may be defined as networks, norms and trusts that exist among people staying together and contribute money capital, human capital and labour capital to the benefit of each member of an union or a society. Money capital is the cash contribution made by individual members of the union base on per capita income or salary. In addition, human capital is contribution of cognitive ability by each member of the union depending on individual educational qualification and discipline. The social capital construct in this study was subjectively measured instead of objective type of measurement. This is because there is no single unit of measuring the variable. Different 
proxies are employed to measure social capital by different research scholars because of the generic nature of the definition. According to Sabatini (2013), different scholars used different proxies such as culture; electoral participation and blood donation; trust and civic participation; density of membership and heterogeneity index; number of voluntary associations, number of newspaper readers and number of people who turns out at referenda to measure social capital. The heterogeneity index is measured on a scale from 0 to 100 , the extent through which membership of an association is internally diversified. This is based on nine (9) criteria namely, neighborhood, kin group, occupation, economic status, religion, gender, age, level of education and political affiliation. Hence, when two or more people come together and contribute knowledge, effort/energy and money jointly, it increases their income generation, expenditure per capita income and poverty alleviation.

\subsection{Consumption per capita income}

Consumption is expense an individual incurred on food, clothing and shelter but not expenses incurred in the process of production of goods and services. Consumption is an individual or a firm expenditure depending on his or her disposable income. The disposable income is gross earnings of individual or firm which taxes (such as PAYE or income tax) have been deducted. When essential expenditure (such as on food, clothing, shelter) is deducted from the disposable income, the balance is called discretionary income which the income earner is free to spend or save (Business Dictionary, 2015). Consumption is also defined as final purchases of goods and services by individuals. Thus, measurement of consumption in this study is expenditure incurred to purchase food, cloth, shelter or others depending on disposable income by members of the cooperative society.

\subsection{Related Empirical Literature on Cooperative Society}

Literature on cooperative Society or union is not farfetched. Magali (2013) examines factors affecting credit default risks on samples of 431 borrowers from 37 rural Savings and Credits Cooperative Societies (SACCOS) in Morogoro, Dodoma and Kilimanjaro regions of Tanzania. The study reveals that loan size and years of schooling of borrowers contributed positively to the loan default. However, the study finds that other independent variables such as loan activity, marital status, age, family size, interest, loan duration, value of collateral and borrowers' experiences unfit the regression model. Other factors such as political interference, lack of entrepreneurship and investment analysis skills, embezzlement practiced by leaders and SACCOS' staff, drought, diseases, deaths and other calamities, non- performance of the business, inadequate loans follow-up and lack of loan activities' insurances cover were mentioned to affect the loans default. The study noticed that absence of proper credit risks management techniques resulted into huge amount of overdue loans.

\subsection{Theoretical framework underpinning of the study}

\subsubsection{Social Capital Theory}

Social capital theory focuses on the independent construct/factor - social capital which is operationalized in terms of five dimensions such as: First, network- of lateral associations that varies in density and size occurring among individuals and groups; Second, reciprocity - expectation that short or long term kindness and service will be returned or pay back; Third, trust-willingness to take initiations (or risk) in a social context based on assumptions that others will respond as expected; Fourth, social norms i.e. the unwritten shared values that direct behavior and interaction; Fifth, personal and collective efficacy- the active and willing engagement of criticizes within participative community (Putnam, 2004). In nutshell, social capital theory is social connections based on tangible and intangible benefits of individuals or community in short or in long run. These benefits could be social, psychological, emotional and economical. Thus, the research models of this study presented in the methodology has social capital as an independent variable. This variable is underpinned by social capital theory that relates to economic benefits, trust, network diversity, network size, demographic diversity of members in the associations.

\subsubsection{Theory of Income and Savings behavior}

The two dependent variables (per capita income and poverty reduction) in this study were underpinned by Keynesian absolute income theory and Friedman's permanent income theory. The Keynes' absolute income theory postulates that as income of members of the cooperate associations increases, their consumptions and savings also increase in direct proportional. The Increment in consumptions and savings may improve members' standard of living and reduction of 
poverty. Members' income can be increased by savings and credits as social capital through the cooperative associations. The CT\&CS members earn salary as permanent income. Friedman's permanent income theory assumes that permanent income increases members' consumption without changing its savings level while temporary income change leads to an increase in savings rather than consumption (Nwankwo et. al., 2013). This study uses classical savings theories of Keynes, Friedman, Modigliani, and Duesembery. The economists agree that income and/or wealth is the main driving force behind consumptions and thus savings. But, they disagree on which income should be applied. The Keynesians used current/absolute income, Freidman permanent income, Modigliani developed his own consumption theory based on the permanent income over the life-cycle of a household, and Duesembery focused on relative income.

\section{Methodology}

\subsection{Population, Sampling, Research Design and Method of Data Collection Strategy}

This study adopted descriptive and cross sectional field survey research design. The population of study was 702 academic and non-academic employees male and female who are registered members of CT\&CS of Federal Polytechnic, Bida-Niger State and make monthly cash contribution from their salary to CT\&CS (Muhammed, 2014). The sample of 255 subjects is elicited from the population with the aid of Yaro Yamene's formula of determining sample size (Kelechi, 2008 in Ogbadu, 2009). The study used simple random sampling technique of probability sampling to select 255 subjects of the sample. In this sampling technique every element in the population has a known and equal chance of being selected as a subject (Cavan et al., 2001). However, out of 255 questionnaire distributed and administered to respondents by self-administration of questionnaire, only 233 questionnaire were completed and returned to the researcher with help of research assistant.

\subsection{Operationalization of variables Measurement, Validity and Reliability of Instruments}

The dependent variables are consumption per capita income and poverty alleviation of members of CT\&CS cooperative association. On the other hand, the independent variable is social capital which is the heterogeneity index as adapted by Grootaert in Sabatini (2013). This heterogeneity index constitutes gender, marital status, educational qualification, work status, salary, cash contribution, membership duration and Credit benefitted. Data extracted on these variables were coded using hexagon logic system. This is because heterogeneity index is measured on a scale ranging from 0 to 100 (Grootaert in Sabatini 2013). In addition, binary coding system in most cases provides a good model that is fit for study and produces a robust regression result. The questionnaire designed for this study consists of two (2) main sections. Section A involves demographic questions about gender, marital status, education qualification and work status. But section $B$ is questions in respect to measurement of independents and dependents variables of this study. In this study, Face and content validity assessments by expert in this area of academic discipline and industry were done. The Cronbach alpha coefficient result tests for independent and dependent variables are 0.667 and 0.647 respectively.

\subsection{Method of Data Analysis and Model Specification}

This study uses SPSS to process the data and multiple linear regressions was done to analysis the data. This is because ordinary least square regression is Best Linear Unbiased Estimator (BLUE). The researchers, reject the null hypotheses if the results of this study are significant at $1 \%, 5 \%$ and $10 \%$ level of significance, otherwise the researchers do not reject the null hypotheses because no sufficient reasons for rejection. In these multiple regression models, the dependent variables are per capita income and poverty reduction while the independent variable is the heterogeneity index or variables as social capital. The heterogeneity index in this study adapt the analytical framework of Yusuf (2008), Johannes (2009), Ebi et al. (2013), Alexender et al. (2013) and Grootaert in Sabatini (2013) as shown below:

$$
\begin{aligned}
& \mathrm{Y}_{1}=\alpha+\mathrm{B}_{1} \mathrm{GDR}+\mathrm{B}_{2} \mathrm{MarSt}+\mathrm{B}_{3} \mathrm{EduQual}+\mathrm{B}_{4} \mathrm{WkSt}+\mathrm{B}_{5} \text { IncomePm+ } \mathrm{B}_{6} \text { Msavings }+\mathrm{B}_{7} \mathrm{Mdr}+\mathrm{e} . \\
& \mathrm{Y}_{2}=\alpha+\mathrm{B}_{1} \mathrm{GDR}+\mathrm{B}_{2} \mathrm{MarSt}+\mathrm{B}_{3} \mathrm{EduQual}+\mathrm{B}_{4} \mathrm{WkSt}+\mathrm{B}_{5} \text { IncomePm+ } \mathrm{B}_{6} \text { Msavings }+\mathrm{B}_{7} \mathrm{Mdr}+\mathrm{e} \\
& \text { Where: } \\
& \mathrm{Y}_{1}=\text { Consumption per capita income in cooperative society } \\
& \mathrm{Y}_{2}=\text { Poverty Alleviation of Members in the cooperative society } \\
& \alpha=\text { Constant or Intercept } \\
& \mathrm{B}_{1} \ldots \mathrm{B}_{7}=\text { Régression Coefficients } \\
& \mathrm{GDR}=\text { Gender (Female or male) } \\
& \text { MarSt }=\text { Marital Status (Single or married) }
\end{aligned}
$$$$
\mathrm{Y}_{2}=\alpha+\mathrm{B}_{1} \mathrm{GDR}+\mathrm{B}_{2} \text { MarSt }+\mathrm{B}_{3} \mathrm{EduQual}+\mathrm{B}_{4} \mathrm{WkSt}+\mathrm{B}_{5} \text { IncomePm }+\mathrm{B}_{6} \text { Msavings }+\mathrm{B}_{7} \mathrm{Mdr}+\mathrm{e}
$$ 
EduQual $=$ Highest Educational Qualification

WkSt $=$ Work Status (non -academic or academic staff)

IncomePm = Income per month or Salary per month (monthly income of members of the cooperative)

Msavings $=$ Members Savings or cash contribution of members to the cooperative society per month

$\mathrm{Mdr}=$ Membership Duration in the cooperative society

$\mathrm{e}=$ Error term.

\section{Data Analysis, Interpretation and Discussion of Results}

\subsection{Multiple Regressions Results}

The section presents and analyses the regression results. It also tests the null hypothesis ( $\left.\mathrm{H}_{0}\right)$ relating to the effect of social capital on consumption (see table 1.2).

Table 1.2: Summary of Regression Results (Model One)

\begin{tabular}{|l|c|c|c|c|}
\hline \multirow{2}{*}{ Model } & Coefficients & Standard Error & T & Significance Level \\
\cline { 2 - 3 } Constant (a) & $\boldsymbol{\beta}$ & 0.092 & 8.351 & 0.000 \\
Gender & $0.772^{\star \star *}$ & 0.077 & -1.066 & 0.287 \\
Marital Status & -0.077 & 0.054 & -1.402 & 0.162 \\
Educational Qualification & -0.076 & 0.032 & -2.524 & 0.012 \\
Work Status & $-0.081^{*}$ & 0.054 & 0.294 & 0.769 \\
Membership Duration & 0.016 & 0.029 & 2.494 & 0.013 \\
Income per month & $0.073^{*}$ & 0.320 & 0.878 & 0.381 \\
Members savings & 0.028 & 0.330 & -0.782 & 0.435 \\
R & -0.026 & & & \\
R & 0.258 & & & \\
Adjusted R2 & 0.067 & & & \\
F Statistics & 0.037 & & & \\
Significance of F (P-alpha value $=0.028)$ & $2.291^{*}$ & & & \\
Durbin Watson & $\rightarrow$ & & & \\
\hline
\end{tabular}

Dependent variable: consumption

Significance Level: One percent $\left({ }^{* * *}\right)$, Five percent $\left({ }^{* *}\right)$ and Ten percent $\left({ }^{*}\right)$

Source: Author Computation using SPSS, 2015

The table 1.2 shows the values of estimated linear regression coefficients of gender, marital status, educational qualification, work status, membership duration, income, and savings of members in the CT\&CS with constant $\beta$ value of 0.772. Membership duration has the highest significant positive coefficient $\beta$ value of 0.073 with standard error of $0.029, t$ - value of 2.494 and significance level of $0.013(1 \%)$. Therefore, membership duration has significant positive influence on consumption. This result is similar with the findings of Olalekan and Emmanuel (2012) and Akinleye and Majekodunmi (2012) showing that membership index has significant effect on rural households' welfare in Nigeria. Income has insignificant positive coefficient $\beta$ value of 0.028 with standard error of $0.320, t$ - value of 0.878 and insignificance level of 0.381 . Thus, income has insignificant positive influence on consumption. This result is different from the finding of Baiyegunhi (2013) identifying economic status has significant effect on welfare of members in Msinga, KwaZulu-Natal, South Africa. Work status has insignificant positive coefficient $\beta$ value of 0.016 with standard error of $0.054, t-$ value of 0.294 and insignificance level of 0.769 . Thus, work status has insignificant positive influence on consumption. This result is also different from the finding of Baiyegunhi (2013) revealing that occupation has significant effect on welfare of members in Msinga, KwaZulu-Natal, South Africa.

However, members' savings has the highest insignificant negative coefficient $\beta$ value of -0.026 with standard error of $0.330, t$ - value of -0.782 and insignificance level of 0.435 . Thus, members' savings has insignificant negative influence on consumption. This result is similar with the finding of Olalekan and Emmanuel (2013) that views savings has positively and insignificantly relationship with welfare of members in Nigeria. Marital status has insignificant negative coefficient $\beta$ value of -0.076 with standard error of 0.054 , $t$ - value of -1.402 and insignificance level of 0.162 . Therefore, marital status has insignificant negative influence on consumption. This result is different from the finding of Adepoju and Oni (2012) 
reporting that marital status has significant relationship with household welfare in Nigeria. Gender has insignificant negative coefficient $\beta$ value of -0.077 with standard error of $0.077, t-$ value of -1.066 and insignificance level of 0.287 . Therefore, gender of members has insignificant negative influence on consumption. This result is different from the finding of Adepoju and Oni (2012) and Baiyegunhi (2013) observing that gender has significant effect on members' welfare. Educational qualification has the least significant negative coefficient $\beta$ value of -0.081 with standard error of $0.032, t$ - value of -2.524 and significance level of $0.012(10 \%)$. Hence, educational qualification of members has significant negative influence on consumption. This result is similar with the finding of Ogunrinola (2011) revealing that education qualification has significant effect on earning distribution in Nigeria.

In diagnose test of the model, the values of $R, R^{2}$ and adjusted $R^{2}$ are $0.258,0.067$ and 0.028 respectively. The $R^{2}$ value is the coefficient of correlation that explains the relationship between the dependent and independent variables which is a strong positive relationship. There is no problem of multi collinearity since none of the correlation coefficient values are more than 0.9 (Pallant, 2001). Collinearity or multi collinearity is undesirable situation when one independent variable is a linear function of other independent variables. In addition, the $\mathrm{R}^{2}$ value tells us that 6.7 percent of the variation in the dependent variable (consumption) is explained by the independent variables (social capital) of the model. On the other hand, the adjusted $\mathrm{R}^{2}$ statistic corrects the $\mathrm{R}^{2}$ value to provide a better estimate of the true population. If you have a small sample you may wish to consider reporting adjusted $R^{2}$ is better than normal $R^{2}$ value (Pallant, 2001). The $F$ statistic value (P-alpha) is 2.291 which is significant at $10 \%(0.028)$. There is relative statistical significant contribution as indicated by the Sig. $F$ change value $(0.028)$. This reveals that the model one is relatively fit for this study going by $F$ statistic rule of fitness. The model provides a good fitness for study if the significance of $F$ statistic value is less than $0.005(p<0.005)$ contributing to the prediction of the dependent variable (Pallant, 2001). But, the Durbin Watson (DW) value is 1.709 which is an evidence of relative serial correlation. If the value of DW is less than one (1) as rough rule of thumb, there may be cause for alarm. This means there are dual standards of measuring the model fitness. Looking at the model fitness, the model is fit for this study.

From the investigation, educational qualification and membership duration as social capital indicators have influence on consumption which are both significant at 10\%. However, gender, marital status, work status, income and savings have insignificant influence on consumption. Thus, the researchers reject the hypothesis $\mathrm{H}_{1}$ relating to educational qualification and membership duration while the researchers accept $\mathrm{H}_{01}$ relating to gender, marital status, work status, income and savings because no sufficient reason for rejection.

\subsection{Multiple Regressions Results}

The section presents and analyses the regression results. It also tests the null hypothesis $\left(\mathrm{Ho}_{2}\right)$ relating to the effect of social capital on poverty alleviation (see table 1.3).

Table 1.3 Summary of Regression Results

\begin{tabular}{|c|c|c|c|c|}
\hline \multirow[b]{2}{*}{ Model } & Coefficients & \multirow{2}{*}{ Standard Error } & \multirow{2}{*}{$\mathrm{T}$} & \multirow{2}{*}{ Significance Level } \\
\hline & $\beta$ & & & \\
\hline Constant (a) & $0.689^{* * *}$ & 0.082 & 8.411 & 0.000 \\
\hline Gender & -0.068 & 0.064 & -1.059 & 0.291 \\
\hline Marital Status & -0.044 & 0.048 & -0.913 & 0.362 \\
\hline Educational Qualification & $-0.056^{*}$ & 0.028 & -1.977 & 0.049 \\
\hline Work Status & 0.049 & 0.048 & 1.035 & 0.302 \\
\hline Membership Duration & 0.034 & 0.028 & 1.293 & 0.197 \\
\hline Income per month & $0.048^{*}$ & 0.028 & 1.690 & 0.092 \\
\hline Members savings & 0.029 & 0.029 & 0.991 & 0.323 \\
\hline $\mathrm{R}$ & 0.248 & & & \\
\hline $\mathrm{R}^{2}$ & 0.061 & & & \\
\hline Adjusted $\mathrm{R}^{2}$ & 0.032 & & & \\
\hline F Statistics & $2.106^{*}$ & & & \\
\hline Significance of $F(P$-alpha value $=0.044)$ & $\rightarrow$ & $\rightarrow$ & $\rightarrow$ & 0.044 \\
\hline Durbin Watson & 1.666 & & & \\
\hline
\end{tabular}

Dependent variable: Poverty alleviation

Significance Level: One percent $\left(^{* * *}\right)$, Five percent $\left({ }^{* *}\right)$ and Ten percent $\left({ }^{*}\right)$

Source: Author Computation using SPSS, 2015 
The table 1.3 indicates the values of estimated linear regression coefficients of gender, marital status, educational qualification, work status, membership duration, income, and savings of members in the CT\&CS with constant $\beta$ value of 0.689 . Work status has the highest insignificant positive coefficient $\beta$ value of 0.049 with standard error of $0.048, t$ - value of 0.035 and insignificance level of 0.302 . Thus, work status has insignificant positive influence on poverty alleviation. This result is different from the finding of Baiyegunhi (2013) revealing that occupation has significant effect on welfare of members in Msinga, KwaZulu-Natal, South Africa. Income has significant positive coefficient $\beta$ value of 0.048 with standard error of $0.028, t$ - value of 1.690 and significance level of $0.092(10 \%)$. Thus, income has significant positive influence on poverty alleviation. This result is the same with the finding of ljaiya et al. (2012) that found social capital indicators have significant relationship with poverty reduction. Membership duration has the highest insignificant positive coefficient $\beta$ value of 0.034 with standard error of $0.028, t$ - value of 1.293 and significance level of 0.197 . Therefore, membership duration has insignificant positive influence on poverty alleviation. This result is different from the findings of Olalekan and Emmanuel (2012) and Akinleye and Majekodunmi (2012) showing that membership index has significant effect on rural households' welfare in Nigeria. Members' savings has insignificant positive coefficient $\beta$ value of 0.029 with standard error of $0.029, t$ - value of 0.991 and insignificance level of 0.323 . Thus, members' savings has insignificant positive influence on poverty alleviation. This result is similar with the finding of Olalekan and Emmaual (2012) that views savings has positively and insignificantly relation with welfare of members in Nigeria.

However, marital status has the highest insignificant negative coefficient $\beta$ value of -0.044 with standard error of $0.048, t$ - value of -0.913 and insignificance level of 0.362 . Therefore, marital status has insignificant negative influence on poverty alleviation. This result is different from the finding of Adepoju and Oni (2012) reporting that marital status has significant relationship with household welfare in Nigeria. Educational qualification has significant negative coefficient $\beta$ value of -0.056 with standard error of $0.028, t$ - value of -1.977 and significance level of $0.049(10 \%)$. Hence, educational qualification of members has significant negative influence on poverty alleviation. This result is similar with the finding of Ogunrinola (2011) observing that education has significant effect on earning distribution in Nigeria. Gender has the least insignificant negative coefficient $\beta$ value of -0.068 with standard error of $0.064, t$ - value of -1.059 and insignificance level of 0.291 . Therefore, gender of members has insignificant negative influence on poverty alleviation. This result is different from the finding of Adepoju and Oni (2012) and Baiyegunhi (2013) indicating that gender has significant effect on members' welfare.

In diagnose test of the model two, the values of $R, R^{2}$ and adjusted $R^{2}$ are $0.248,0.061$ and 0.032 respectively. The $R^{2}$ value is the coefficient of correlation that explains the relationship between the dependent and independent variables which is a strong positive relationship. There is no problem of multi collinearity since none of the correlation coefficient values are more than 0.9 (Pallant, 2001). Collinearity or multi collinearity is undesirable situation when one independent variable is a linear function of other independent variables. In addition, the $R^{2}$ value tells us that 6.1 percent of the variation in the dependent variable (poverty alleviation) is explained by the independent variables (social capital indicators) of the model. On the other hand, the adjusted $R^{2}$ statistic corrects the $R^{2}$ value to provide a better estimate of the true population. If you have a small sample you may wish to consider reporting adjusted $R^{2}$ is better than normal $R^{2}$ value (Pallant, 2001). The $\mathrm{F}$ statistic value (P-alpha) is 2.109 which is significant at $10 \%(0.044)$. There is relative statistical significant contribution as indicated by the Sig. $F$ change value $(0.028)$. This reveals that the model one is relatively fit for this study going by $\mathrm{F}$ statistic rule of fitness. The model provides a good fitness for study if the significance of $F$ statistic value is less than $0.005(p<0.005)$ contributing to the prediction of the dependent variable (Pallant, 2001). But, the Durbin Watson (DW) value is 1.666 which is an evidence of relative serial correlation. If the value of DW is less than one (1) as rough rule of thumb, there may be cause for alarm. This means there are dual standards of measuring the model fitness. Looking at the model fitness, the model is fit for this study. From the result of finding, income and educational qualification as social capital variables have influence on poverty alleviation which are both significant at $10 \%$. Though, gender, marital status, work status, membership duration and members' savings have insignificant influence on poverty alleviation. Thus, the researchers reject the hypothesis $\mathrm{Ho}_{2}$ relating to income and educational qualification of members while the researchers accept $\mathrm{Ho}_{2}$ relating to gender, marital status, work status, membership duration and savings because no sufficient reason for rejection.

\section{Conclusion of Major Findings}

The regression results of model one shows that social capital indicators like educational qualification and membership duration have significant influence on consumption. The researchers therefore, reject the null hypothesis relating to educational qualification and membership duration of social capital. This is because the results are different from hypothesis $\mathrm{HO}_{1}$ stating that social capital has no significant influence on consumption. This means educational 
qualification and membership duration will significantly influence consumption. However, the researchers accept $\mathrm{H}_{1}$ relating to gender, marital status, work status, income and savings of social capital because no sufficient reason for rejection.

The regression results of model two reveals that social capital proxies like income and educational qualification have significant influence on poverty alleviation. The researchers therefore, reject the null hypothesis relating to educational qualification and membership duration of social capital. This is because the results are different from hypothesis $\mathrm{Ho}_{2}$ stating that social capital has no significant influence on poverty alleviation. This discloses that educational qualification and membership duration will significantly influence poverty alleviation. But, the researchers accept $\mathrm{Ho}_{2}$ relating to gender, marital status, work status, membership duration and savings of social capital because no sufficient reason for rejection. Thus, these results are unique and contribute to knowledge by revealing that social capital index like educational qualification and membership duration has significant influence on consumption. Also, social capital index like income and educational qualification has significant influence on poverty alleviation in CT\&CS of Federal Polytechnic Bida, Niger state.

\section{Limitations of Study}

The first constraint is that different proxies are utilized to measure social capital variables which the researcher adapts one after making some modifications. Secondly, the findings of this study cannot be generalized in all tertiary institutions that have cooperative associations across countries because of the differences in standard of living of members.

\section{Recommendations}

The cooperative society helps in mobilizing savings from members' income in order to enhance consumption and alleviate poverty. The cooperative society functions and actions are tailored toward membership benefits. The managerial team of the cooperative has to formulate policies on proxies influencing consumption and poverty alleviation of the members. This is because social capital index like educational qualification and membership duration has significant influence on consumption while social capital indicator like income and educational qualification has significant influence on poverty alleviation in Cooperative Thrift and Credit Society (CT\&CS) of Federal Polytechnic Bida, Niger state. These results concord and contradict some of the findings of Oguninola (2011); Olalekan and Emmanuel (2012); Akinleye and Majekodunmi (2012); ljaiya et al. (2012) and Baiyegunhi (2013). Therefore, the study recommends that regulators and policy makers should encourage savings mobilization from members' income or salary in order to boost consumption and alleviate poverty. This is because income has insignificant influence on consumption and significant influence on poverty alleviation in CT\&CS of Federal Polytechnic Bida, Niger state.

\section{References}

Adepoju, A.A. and Oni, O.A. (2012). Investigating Endogeneity Effects of Social Capital on Household Welfare in Nigeria: A Control Function Approach. Quarterly Journal of International Agriculture, 51 (1): 73-96. Retrieved 24th July, 2014, from http://ageconsearch.umn.edu/bitstream/155473/2/4_Adepoju.pdf.

Akinleye, O. and Majekodunmi, A. (2012). Determinants of Social Capital and Sundry Variables on Household Wellbeing in South western Nigeria. International Journal of Advanced Research in Management and Social Sciences, 1 (2): 18-34, August 2012. Retrieved 24th July, 2014, from http://www.garph.co.uk/IJARMSS/Aug2012/2.pdf

Baiyegunhi, L.J.S. (2013). Rural households' social capital and welfare: A case study of Msinga, KwaZulu-Natal, South Africa. Journal of Agriculture and Rural Development in the Tropics and Subtropics, 114 (2): 123-132. Retrieved 24th July, 2014 from http://www.jarts.info/index.php/jarts/article/viewFile/2013081343356/788

Business Dictionary (2015). Disposable income. Retrieved July 18, 2015 from http://dictionary.cambridge.org/dictionary/businessenglish/consumptionBellù, L.G Liberati, P. (2005). "Impacts of Policies on Poverty". Food and Agriculture Organization of the United Nations, FAO. Retrieved 24th July, 2014.

Ebi, B.; Okon, E. N. and Ubi, P. (2013). Social Capital and Economic Growth Opportunities: A Case Study of Rural Households in Obudu, Cross River State, Nigeria. Global Journal of Human Social Science Economics, 13 (2): 13-16. Retrieved 24th July, 2014, from https://globaljournals.org/GJHSS_Volume13/3-Social-Capital-and-Economic-Growth.pdf

Cavana, R. Y., Dalahaye, B., \& Sekaran, U. (2001). Applied Research: Qualitative and quantitative methods. Australia: John Wiley and sons

Ibrahim, S.I. and Mohammed, A. (2009). Housing Quality Study in Barkin Saleh, Minna, Niger State. Lapai International Journal of Management and Social Science (LIJOMASS), 2 (1): $119-134$.

ljaiya, M.A. A.; Sakariyau, O.B.; Dauda, C.K.; Paiko. I. I. and Zubairu, U.M. (2012). Social Capital and Poverty Reduction in Nigeria: A 
Case Study of Minna Metropolis. International Journal of Business and Social Science, 3 (12): 229-235, Special Issue - June 2012. Retrieved July 24, 2014, from http://ijbssnet.com/journals/Vol_3_No_12_Special_Issue_June_2012/23.pdf.

Johannes, T.A. (2009). "Does Social Capital Determine Poverty?" Evidence from Cameroon Household Survey. Prepared for Presentation at the GLOBELICS (Global Network for Economics of Learning, Innovation, and Competence Building Systems) 2009 Conference: UNU-MERIT (Maastricht, the Netherlands) CRES, UCAD (Dakar, Senegal) October 6-8, 2009, PP: 1-25. Retrieved 24th July, 2014, from https://smartech.gatech.edu/bitstream/handle/1853/36695/Paper\%20Globelics.pdf

Magali, J.J. (2013). Factors Affecting Credit Default Risks For Rural Savings and Credits Cooperative Societies (SACCOS) in Tanzania. European Journal of Business and Management, 5 (32): 60- 73. Retrieved August 20, 2014 from http://www.iiste.org/Journals/index.php/EJBM/article/download/9559/9692

Nwankwo, F.; Ewuim, N. and Asoya, N.P. (2013). Effect of Cooperatives on the Savings Behaviour of Members in Oyi Local Government Area, Anambra State, Nigeria. An International Multidisciplinary Journal, Ethiopia, 7 (28): 209-227 January Retrieved August 20, 2014 from http://www.ajol.info/index.php/afrrev/article/download/88241/77886

Nyasulu, G. (2010). Revisiting the Definition of Poverty. Journal of Sustainable Development in Africa, 12 (2): 147-158, Retrieved October 31, 2013, from www.jsd-africa.com/.../Revisiting\%20the\%20Definition\%20of\%20Povert...

Ogbadu, E.E. (2009).Profitability Through Effective Management of Material. Journal of Economics and International Finance, 1 (4): 099-1055. Retrieved April 14, 2012, from www.academic journal.org/jeif/pdf/pdf 2009/sep/ogbadu.pdf.

Ogunrinola, O. (2011) Social capital and earnings distribution among female micro-entrepreneurs in rural Nigeria, African Journal of Economic and Management Studies, 2 (1): 94-113. Retrieved 24th July, 2014, from http://www.emeraldinsight.com/journals.htm?articleid=1918183

Olalekan, O.S. and Emmanuel, O.S. (2012). Social Capital and Rural Households Welfare in Surulere Local Government Area, Oyo State, Nigeria. Interdisciplinary Journal of Contemporary Research in Business, 3 (11), 388-405, March 2012, Retrieved 24th July, 2014, from http://journal-archieves16.webs.com/388-405.pdf

Oseni, M.; Ogunniyi, O.R. and Sanni, M. R. (2012). Cooperative Societies Investments \& Retiring Members: A Fair Returns Assessment. European Journal of Globalization and Development Research, 5 (1): 313-328. Retrieved August 20, 2014 from http://www.journalsbank.com/ejgdr_5_5.pdf

Pallant, J. (2001). SPSS Survival Manual. A Step by Step Guide to Data Analysis Using Statistical Package for Social Science._First Edition, Open University Press McGraw-Hill Education McGraw-Hill HouseShoppenhangers Road Maidenhead Berkshire. Available at www.openup.co.uk/spss.

Sabatini, F. (2013) "Social capital and Economic Development". Lectures for the Master in Non-Farm Activities and Rural Development in Developing Countries, University of Rome La Sapienza. Retrieved July, 2014, from http://w3.uniroma1.it/spes/lecture\%2001.pdf.

Yusuf, N.; Gafar, T. and Ajaiya, M.A. (2009). Informal Financial Institutions and Poverty Reduction in the Informal Sector of Offa Town, Kwara State: A Case Study of Rotational Saving and Credit Associations (RSCAs). Journal of Social Sciences 20 (1): 71-81. Retrieved January 13, 2011, from www.krepublishers.com/.../Jss-20-01-071-09-605-Yusuf-N-Tt.pdf.

Yusuf, S.A. (2008). Social Capital and Household Welfare in Kwara State, Nigeria. Journal Human Economics 23 (3): 219-229 (2008). Retrieved 24th July, 2014, from http://www.krepublishers.com/02-Journals/JHE/JHE-23-0-000-000-2008-Web/JHE-23-3-000-0002008-Abst-PDF/JHE-23-3-219-08-1714-Yusuf-S-A/JHE-23-3-219-08-1714-Yusuf-S-A-Tt.pdf 